\title{
GMO Trees: Substantial promise but serious obstacles to commercialization
}

\author{
By R. A. SEDJO ${ }^{1)}$
}

(Received: April 24, 2006/Accepted: September 2, 2006)

\begin{abstract}
Summary
This paper assesses the potential of transgenic trees to generate substantial financial returns in an environmental where there are substantial investment costs in research and development, deregulation and deployment. The formidable obstacles and in addition to the usual research and development costs, include the costs of obtaining requisite intellectual property rights. Also, there are substantial costs to achieve deregulation, and some evidence of deregulatory slowdown in the U.S., and cost of product deployment. The product deployment costs are likely to be higher than for other products, e.g., traditionally improved seedlings, due to substantial and widespread opposition (stigma) to GE in general and transgenic trees particular. As with all trees, the payoff time (harvest) is delayed longer than most other investments and the financial returns adversely affected by the delay. Additionally, the financial costs and benefits may vary substantially by country and region. Some evidence suggests that deregulation costs may vary substantially by country. Additionally, the perceived "stigma" costs are likely to vary greatly among regions thereby providing better opportunities in some markets than others. If deployment depends upon the financial and economic returns, one might expect widespread adoption among some countries, e.g., China and Brazil, where the net benefits are large, and little or no adoption among countries where the net benefits are small, e.g., countries of the EU. However, at this time the final success of GE trees remains to be witnessed. Although some firms have withdrawn entirely from the area of tree GE research, other firms continue to invest substantial sums in tree GE development presumably anticipating eventual payoffs. It remains to be determined whether the technology ultimately is broadly accepted, accepted only regionally or fails globally.
\end{abstract}

Key words: Genetic engineering, trees, transgenic, harvests.

\section{Introduction}

Anticipation of a biotechnology revolution has led to high expectations. In a number of crops biotechnology, and particularly GE (transgenic) agricultural plants have achieved a large degree of success. Crops such as soybean, cotton and corn have found clear financial advantages associated with the new transgenic agricultural product. Examples of successes in agriculture include herbicide resistant soybean, pest resistant (Bt) cotton and, in trees, disease resistant papaya. These have been readily accepted despite the somewhat higher cost of seed and opposition in consumer markets in some countries. Evidence of success is found in the fact that the area of agricultural GE crops increased from 2.8 to

\footnotetext{
1) Senior Fellow and Director of the Forest Economics and Policy Program, Resources for the Future, Washington, DC. E-Mail: sedjo@rff.org
}

67.7 million hectares worldwide between 1996 and 2003 . Agricultural GE crops were being grown commercially in 18 countries (FAO, 2004).

However, some of these expectations may be damping. In some areas the expectations for commercialization seem to have been overly optimistic for a variety of reasons (Nightingale and MARTin, 2004) and TraXleR (2005) argues that recent commercial innovations in agriculture have tended to be of only a few limited types. An area that has been slow to develop is that of tree biotechnology. In general, transgenic trees have made little deregulatory and commercial progress with a very few exceptions. Genetically engineered trees designed for the production of wood for industrial purposes, e.g. lumber and paper, have not yet been deregulated or commercialized. In a recent article M. H. ElLakany, Assistant Director General of FAO and Head of the Forestry Department raise the question of the adequacy of financial returns in forestry when he suggested that the economic rationale for investing in genetically modified forest trees for commercial application is not directly apparent (EL-LAKANY, 2004).

In the absence of planted forests, transgenic trees would impart few economic advantages. However, with the advent of intensively managed planted forests over the past few decades, the value of improved trees, including through genetic engineering, has become potentially more important. During the past 30 years, industrial plantation forests have become a major supplier of industrial wood, gradually displacing that gathered from natural forests. Today, while industrial forest plantations constitute only about $2.5 \%$ of the world's forested area of 3.9 billion ha, they account for roughly one-third of the world's industrial wood production (CARLE et al., 2003). Since more of the plantation production has come on stream over the past 25 years, and total global industrial wood production has barely increased over that period, the total harvest from natural forest has undoubtedly decreased absolutely as well as its share. Projections estimate that plantations are expected to account for $50 \%$ of global industrial wood production by 2025 and $75 \%$ by 2050 (SOHNGEN et al., 1999). Such a shift would almost surely reduce even further the industrial logging pressures on existing natural forests.

Reasons for the success of tree plantations include the improving economics of planted forests through intensively managed forestry, particularly in certain regions with soils and climate conducive to rapid growth. The U.S. South provides an example. Additionally, certain regions that had not previously been major wood producers have recently become important both domestically and internationally. This has been particularly true in 
Table 1. - Gains from Various Traditional Breeding Approaches: Loblolly Pine.

\begin{tabular}{|l|l|}
\hline Technique & Effect (increase in yields) \\
$\begin{array}{l}\text { Orchard Mix, open pollination, } \\
\text { first generation }\end{array}$ & $8 \%$ \\
$\begin{array}{l}\text { Family Block, best mothers } \\
\text { Mass Pollination (control for both male } \\
\text { and female) }\end{array}$ & $11 \%$ \\
\hline
\end{tabular}

Source: Westvaco Corporation, 2000, Summerville, NC.

parts of the subtropics, where countries like New Zealand, Chile, Brazil and South Africa have become major industrial wood producers within the last few decades.

Many of these sites have experienced improved tree germplasm, achieved through traditional breeding approaches that often do extremely well in their new environment. These emerging opportunities have elicited large efforts in tree improvement and have been focused, for example, on certain species of pine, poplar and eucalyptus (table 1). Additionally, tree traditional breeding can often generate enhanced net financial returns for improved indigenous species (ANDERSON and LUCKERT, 2004).

These innovations have involved a substantial restructuring and relocation of the forest products industry, which can now be seen as a part of the broader worldwide phenomenon of globalization (BOWYER, 2004). Simultaneously, the relative costs of wood from natural forests are generally increasing, due to increasing extraction costs often associated with increased logging costs due to stricter forest practice regulations, and increases in the establishment of protected and set-aside areas. ${ }^{2)}$ Under such a situation it would seem that the opportunities for the development and deployment of transgenic forest trees would be substantial.

In recent decades, traditional breeding techniques have been practiced in forestry as they have been for some time in agriculture. As with agriculture, early plant improvements involved identification of trees (plants) with desired traits and attempts to capture and breed offspring that had the desired traits through the identification of "superior" trees.

As in much of agriculture, the benefits from the introduction of biotechnology and transgenics would fall largely on monoculture type tree plantations and probably be less useful to programs using diverse tree species. However, to a forest industry that is already shifting increasingly to an intensive planted mode, the benefits seem to be potentially large. Innovations include modification of lignin, which will reduce processing costs in the digester, and Bt genes, which should reduce pesticide costs. Recently, some field test successes have been gained through the explicit introduction of genes that promote enhanced rates of biological growth (WELLS, 2006). The economic benefits of transgenics are ultimately expected be found in the form of lower produc-

\footnotetext{
2) For example, harvests in 2003 from US National Forests were less that $18 \%$ of what they had been fifteen years earlier, reflecting the declining use of these natural forests for timber production purposes.
}

tion costs per unit of output and therefore increased profitability to firms and increased availability and affordability to consumers of wood and wood products. This would be achieved both by producing wood with traits that lower the costs of processing and by producing wood with superior use characteristics.

In addition to financial and economic benefits, environmental benefits can be found, for example, in reduced requirements for chemical pesticides. Additionally, an implication of the increased productivity of planted forests is that large areas of natural forest could be freed from pressures to produce industrial wood, perhaps thereby being better able to provide a more environmental benefits and a more biodiverse habitat.

Also, there are other nonindustrial wood benefits that could be obtained from the application of transgenics, e.g., trees with phytoremediation properties could provide a clean-up technology. Such an approach exploits the actions of plants and their associated microbes to alleviate hazardous soil contamination, could be substantial (e.g., see Doty et al., 2000). Other environmental opportunities are through the application of biotechnology to habitats under pressure either from an exotic disease, as with the American chestnut tree (Castenea dentafa) in the United States (BAILEY, 1997), or from invasive exotics.

While the promise appears great, the economic and location based obstacles to commercial use are formidable and may preclude achieving their benefits. Long development lead times and rotations erode much of the financial benefit. Patent and licensing costs, deregulation and other legal issues could make the total development costs prohibitive. The lack of public acceptance of transgenic trees may preclude its wide commercial application. There is strong opposition. For example, the Forest Stewardship Council program denies certification to transgenic trees. ${ }^{3)}$ More seriously perhaps is the current United Nations Environment Programme (UNEP), acting through the Convention on Biological Diversity (CBD) is considering a worldwide moratorium on the field testing and commercial releases of genetically modified trees (CBD, 2006).

\section{The Adequacy of Financial Returns}

The unsettledness of acceptance and markets for GE trees has resulted in many companies choosing not to

\footnotetext{
3) However, other certifying groups are silent on the question and indeed standards change. An earlier FSC standard was to deny certification to plantation forests. This standard has subsequently been dropped.
} 
make investments or further investments in the development of transgenic trees. Monsanto, for example, made a decision in the late 1990s to focus its efforts on the application of its transgenic technology to major crops and eliminate efforts in minor crops including forest trees. It has, however, allowed its existing tree technology to be available to third parties for further development and commercialization. Implicit in this action is the view that the financial returns for forest trees were more problematical than for major crops, probably due to problems of acceptance as well as to the relatively small size of the potential markets. On the other hand, firms that are continuing to invest in research to develop viable transgenic trees for commercial uses presumably believe that the obstacles are manageable and long run generate profitability is possible.

Although it is clear that the financial returns to transgenic biotechnology have been adequate to generate a number of new medicinal and agricultural products, the question is open as to whether there are applications of transgenic biotechnology that will generate innovative forest tree products with sufficient incremental market values to justify the total investment costs. Since new developments and the commercial applications of technology typically involve substantial financial investments over time, this paper examines the nature of these investment costs as well as some of the differences between long-lived tree products and annual agricultural crops.

The purpose of this paper is to examine the barriers to profitability and speculate as to what types of conditions provide the best opportunities for firm and countries to achieve profitability. This paper asks "what are the major impediments, financial, economic, and social to the widespread commercial application of GE trees?" In addition, the financial components are related to various countries and locations and an assessment is made of where transgenic trees are likely to generate the highest returns and therefore where they may be initially released for commercialization.

\section{Some Financial Basics of Transgenic Tree Development}

Investments are typically characterized by costs in the early years associated with the investment followed by revenues or returns in the later years generated by the investment. The question of financial viability asks whether the returns in the later years are sufficient to justify the earlier investment costs. Since these costs and returns occur at different points in time, the discount rate is used to "normalize" the costs and returns to a common time period. Various investment criteria are used including benefit-cost ratios, discounted present values or internal rates of return. ${ }^{4}$ Each of these can be used to determine whether the investment generates a stream of earnings through time that, adjusted by

${ }^{4)}$ Whereas the benefit-cost ratio and the discounted present value use a predetermined (exogenous) discount rate, the internal rate of return solves for the discount rate that equates intertemporal costs and benefits. the appropriate discount rate, equals or exceeds the stream of discounted costs.5) This relationship determines whether the investment generates a net positive return through time when gross costs and returns are adjusted by the discount rate, i.e., when the time costs of capital, are considered. Of course, higher returns are preferred to lower returns, other thing being equal. The general rule is that the:

Cost of the investment, adjusted for time by the discount rate $<$ Sum of the value of the benefits, adjusted for time by the discount rate.

Alternatively, one might require an investment generate a rate of return in excess of some minimum. This is the internal rate of return (IRR) criterion. For example, the investor might require that an acceptable investment must generate an internal rate of return of at least some level, e.g., 10 percent. The cost of the investment in this context involves a variety of considerations, which are discussed below. The value of the benefits reflects prices and volumes. A poor reception by consumers, for whatever reason, implies low prices, volumes and ultimately values.

The above formulation suggests, and it is well recognized in the financial literature and among most foresters, that returns in the near future are preferable to returns in the distant future. Because of the longlived nature of most trees and the time discounting common in financial assessment, trees have certain financial disadvantages compared to, e.g., annual agricultural crops. Foresters have understood the financial disadvantages of long rotation forestry since at least 1849 when the famous FAUSTMANN (see 1995 reprint) paper was first published. An implication of the above discussion is that for the same initial investment costs many short cycle (annual) GE crops could general acceptable financial returns while tree crops delivering the same total value, but delayed, might not be financially viable. Thus, the hurdles are more difficult for long-lived trees than annual crops, other thing being equal.

A second implication is that shorter tree-rotations are financially preferable to longer rotations, other things being equal. Thus, it is not surprising that most tree plantations focus on species with short rotations and tree improvement innovations are directed at increasing tree values or decreasing costs. It should be noted, however, that despite the disadvantage of the long gestation time, planting trees has been demonstrated to be a financially viable investment in many situations.

Finally, there is the question of uncertainty. To the extent that the various components of cost have large elements that are either unknown or are dependent upon events outside of the developers' control, e.g., the possibility of a UN moratorium on GE tree deployment, the expected return becomes cloudy and the variability around that expected return increases. It is well know that investors tend to avoid uncertainly.

\footnotetext{
5 ) The literature has determined that the discounted present value is the most accurate criterion, although the various criteria are often used almost interchangeably.
} 


\begin{tabular}{|c|c|c|c|c|}
\hline Stage I & Stage II & Stage III & Stage IV & Stage $V$ \\
\hline $\begin{array}{l}\text { development } \\
\text { costs: } R \& D, \\
\text { patent, license, etc. }\end{array}$ & $\begin{array}{l}\text { deregulation costs } \\
\text { (for transgenics } \\
\text { only) }\end{array}$ & $\begin{array}{l}\text { Distribution/marketing } \\
\text { costs to producers: } \\
\text { (including stigma costs } \\
\text { unique to transgenics) }\end{array}$ & $\begin{array}{l}\text { Stigma costs } \\
\text { to final } \\
\text { consumers } \\
\text { and/or } \\
\text { environmental } \\
\text { community }\end{array}$ & $\begin{array}{l}\text { time } \\
\text { costs: } \\
\text { planting } \\
\text { to } \\
\text { market }\end{array}$ \\
\hline
\end{tabular}

Figure 1. - Investment Stages for Conventionally Breed and Transgenic Trees.

\section{Investment Costs in Improved Forest Trees}

\section{Investment Stages}

Starting with a stock of basic research knowledge, one can think of the development of improved tree products as involving a number of types or stages of investments, ${ }^{6)}$ Two types of innovations are examined: innovations generated through traditional tree breeding techniques and tree innovations achieved through genetic engineering, with the focus on those using genetic engineering. First, the costs are those of research and development, which here include costs associate with the use or purchase of any required intellectual property via patents, licenses, including legal fees, etc. Second, investment costs in deregulation, ${ }^{7)}$ which is not required for trees improved through traditional breeding techniques. Again, substantial legal costs etc. may be involved. Third, investment costs in marketing and distribution of the product to the farmer or forester producer. This may include marketing to mitigate producers concerns with the production approach (stigma ${ }^{8)}$ ). Where the product may meet opposition from final consumers or the environmental community (stigma), costs may need to be incurred to mitigate that opposition if the product is to be successful. Finally, as noted, there are time costs required in forestry that are not required for annual agricultural crops.

Figure 1 lays out five investment (cost) stages in the development of a new transgenic forest tree. These are the initial development costs, deregulations cost for a transgenic, distribution costs, and time costs to the grower between planting and receiving financial returns. If the improved tree is transgenic, in addition to deregulation costs, one might expect some additional distribution costs to overcome the GE stigma that may be present in many markets.

Specifically, investments costs for a innovative transgenic tree typically consist of: 1) the development costs, including requisite licensing costs for requisite patents, etc., for the new product, e.g., the herbicide tolerant

6) TRAXLER (2005) distinguishes between targeted technology research, where very large funding is required leaving this activity to only the larger firms and/or government, and spillover benefits from earlier research, which can be achieved at much less cost drawing on the earlier research findings. Here we refer principally to spill-over research

$\left.{ }^{7}\right)$ Some have argued that the regulator system is becoming slower and more ownerious. See data in SEDJO (2004).

8) Stigma is a term developed in the economics literature that denotes a negative attitude toward a particular product or product process. It refers to the social attitude but says nothing about whether that attitude is justified. Stigma is reflected in a reduced demand for the product and perhaps political action against the product and/or process. gene as applied to a particular plantations tree; 2) the deregulation investment costs for the new transgenic product, given that in most countries a transgenic plant is automatically a regulated article requiring deregulation for commercial use (note again that these costs are not required for a tree improved through traditional breeding); 3) the costs required for investment in a distribution system for the product, e.g., advertising, sales distributors, etc. (note that overcoming public opposition to a transgenic, its stigma, might require additional distribution costs for a transgenic but not for a tree improved through traditional breeding); 4) costs to mitigate opposition by final consumers and environmental groups, and 5) the time costs between when the tree is planted and when these benefits are captured and monetized, i.e., an issue common in long-lived trees.

These comments suggest that, other things being equal, the nontrangenic tree would be preferred by the developer since some important investment costs could be avoided, specifically deregulation and stigma costs. Of course, other things are not always equal.

In addition, while stigma may be an important cost, it need not be prohibitive. This has been demonstrated in crop agriculture where, despite substantial deregulation and stigma, major GE crop innovations have successfully been commercialized in many countries of the world. Of course, a major rationale for genetic engineering is that it often allows transformations to be accomplished at lower investment development costs than would traditional breeding. Perhaps more importantly, asexual GE allows transformations to be executed that cannot be accomplished using traditional sexual breeding approaches (CARSON et al., 2004). Hence, despite the extra investment costs, certain products are possible using only the GE technology. This has been demonstrated in crop agriculture where, despite substantial deregulation and stigma costs, major GE crop innovations have successfully been commercialized in many countries of the world.

\section{Product Development Costs}

The level of investment costs in tree biotech area is difficult to estimate or obtain and product development costs obviously will vary with the particular product. For conventional tree breeding using a well-known species with a short juvenile phase the costs of developing a new forest tree have been estimated at about $\$ 400,000$ and require $15-20$ years to be developed (Fenning and Gershenzon, 2002).

For larger more complicated operations the costs will be higher. It is estimated that the New Zealand Forest 
Research Institute spent about US $\$ 20$ million (1989 dollars) on tree improvement research and development over the period 1959-1989. Also, while somatic embryogenesis research is directed only at pine, this research alone throughout New Zealand is estimated to have cost about US $\$ 30$ million over a $10-15$ year period (CARSON et al., 2004, p 30).

As noted in Figure 1, where either traditional or transgenic development approaches can be used for the development of a similar new tree at roughly the same costs through time, the conventional breeding approach would almost certainly be used since it avoids the costs of deregulation (Stage II) ${ }^{9)}$ and the additional costs of overcoming any consumer stigma associated with the transgenic product (part of Stage III and Stage IV).

However, for transformations where the genes with the desired traits are not found in the species of interest, a transgenic approach would be required to transmit the gene. Also, transgenic approaches may facilitate a more precise transfer of desired genes (since no irrelevant genes need be involved as they would have to be in traditional breeding approaches). ${ }^{10)}$ Finally, some transgenic approaches may offer the potential of reducing the time involved for development of a new tree since the long periods involved in allowing a tree to mature can, in some cases, be circumvented using modern biotechnology or GE approaches. Although still in the early stages, approaches that show promise for reducing the time required to improve long-lived plants like trees include genetic marking, which could identify the genes associated with ageing, and GE transformations, which might reduce the time required to maturity (STRAUSS et al., 2004). ${ }^{11)}$

\section{Market Considerations}

In addition to the price received in the market for the innovation, the total return to the developer also depends on the volume of sales and thus on the size of the market for the innovation. For a major annual crop, the maximum potential market would be all the seed required to meeting planting needs for a given crop each

${ }^{9}$ ) Maud Hinchee of Arborgen (personal conversation, Summerville, N.C. May 2003) has estimated the costs of deregulation for a transgenic tree in the U.S. will be at least $50 \%$ over and above the development costs.

10) See HANCOCK and HoKAnson (2001) for the argument that a transgenic is much less likely to become invasive because only a small number of genes have been modified and these are known.

11) For example, recent work with Arabidopis LEAFY (LFY) has been demonstrated to induce early flowering in transgenic trees (e.g. RotTMAnN et al., 2000; RotTMAnN et al., 2005). year. ${ }^{12)}$ Thus, as a transgenic innovation is adopted by growers, sales increase to some maximum set by the size of the market. Other things being equal, a large market offers greater potential for generating the large revenues needed to allow the developer to cover the costs of the investments and earn a positive return.

By contrast with major crops, the potential market for forestry is probably much smaller since even fast-growing plantation trees are usually planted in harvest rotations of six to thirty years. Thus, new seed stock for a site is required only one time every one-half to three decades, making the annual market associated with a given land area much smaller for forestry than for annual agricultural crops. Additionally, in a dynamic industry the subsequent seed stock offerings will probably be improved over the initial transgenic stock. Thus, the developer may only have one sale per innovation per site thereby limiting the opportunity to generate returns to cover the various investment costs of the innovation.

For an innovation to be financially viable, it must provide enough incremental financial benefits to allow it to be priced attractively to the grower and still allow net financial benefits to be captured by the developer. Thus, the innovation must provide enough cumulative financial returns so as to cover the costs of the firm's investments associated with this innovation and generate a reasonable rate of return on those investments, as well as to provide some financial advantages to the farmer.

\section{Improved Trees and Transgenic Innovations}

In general, the focus of transgenic tree development is to reduce per unit production costs by either lowering wood costs or improving a quality dimension. The usual approach coordinates traditional tree breeding improvements with transgenics. Traditional breeding is usually directed to providing the best basic tree, often with a focus on growth and yield. GE is then applied to add one to several desired traits to this already superior tree. Most of the focus today is directed at producing wood fibre for pulp and paper production with a view to lowering delivered wood costs or reducing mill processing costs.

Table 2 provides a grouping of characteristics and traits of interest in forestry ranging from silvicultural features to environmental adaptability and wood characteristics. Transgenic trees offer the potential of producing a product, industrial wood, with a number of

$\overline{12) \text { TRAXLER }}$ (2005) argues that, due to the large numbers of varieties for most seed crops, these individual markets are much smaller than often believed.

Table 2. - Forest Traits That May Be Improved through further Research.

\begin{tabular}{|l|l|l|}
\hline Silviculture & Adaptability & Wood Quality Traits \\
\hline Growth rate & Drought tolerance & Wood density \\
\hline Nutrient uptake & Cold tolerance & Lignin reduction \\
\hline Crown/stem & Fungal resistance & Lignin extraction \\
\hline Flowering control & Insect resistance & Juvenile fiber \\
\hline Herbicide & & Tree form, Branching \\
\hline
\end{tabular}


Table 3. - Possible Financial Gains from Future Biotech Innovations.

\begin{tabular}{|c|c|c|}
\hline Innovation & Possible Benefits $^{13}$ & Operating Costs \\
\hline Wood density gene & $\begin{array}{l}\text { Improved lumber } \\
\text { strength }\end{array}$ & None \\
\hline $\begin{array}{l}\text { Herbicide tolerance } \\
\text { gene in eucalyptus } \\
\text { (Brazil) }\end{array}$ & $\begin{array}{l}\text { Reduce herbicide and } \\
\text { weeding costs } \\
\text { potentially saving } \$ 350 \\
\text { or } 45 \% \text { per ha }\end{array}$ & None \\
\hline $\begin{array}{l}\text { Improve fiber } \\
\text { characteristic }\end{array}$ & $\begin{array}{l}\text { Reduce digester cost } \\
\text { potential savings of } \$ 10 \\
\text { per } \mathrm{m}^{3}\end{array}$ & None \\
\hline $\begin{array}{l}\text { Reduced amount of } \\
\text { juvenile wood }\end{array}$ & $\begin{array}{l}\text { Increase value } \$ 15 \text { per } \\
\mathrm{m}^{3} \text { (more useable } \\
\text { wood) }\end{array}$ & None \\
\hline Reduce lignin & $\begin{array}{l}\text { Reduce pulping costs } \\
\text { potential of } \$ 15 \text { per } \mathrm{m}^{3}\end{array}$ & None \\
\hline
\end{tabular}

Source: Context Consulting ${ }^{14}$.

\begin{tabular}{lcc}
$\begin{array}{l}\text { Table 4. - Timing of the Capture of Financial Returns of Interest in Forestry. } \\
\text { Trait }\end{array}$ & Early Capture & Captured at Harvest \\
\hline Herbicide tolerance & $\mathrm{X}$ & $\mathrm{X}$ \\
Flowering control & & $\mathrm{X}$ \\
Fiber/Lignin modification & $\mathrm{X}$ & \\
Insect tolerance & $\mathrm{X}$ & $\mathrm{X}$ \\
Disease tolerance & & $\mathrm{X}$ \\
Wood density & & $\mathrm{X}$ \\
Growth & & $\mathrm{X}$ \\
Stem straightness & $\mathrm{X} ?$ & $\mathrm{X} ?$ \\
Nutrient uptake & & \\
Cold, wet, drought tolerance & $\mathrm{X}$
\end{tabular}

desired traits. The transformation can be such that the wood can be more valuable by virtue of: wood quality traits that are either desirable in themselves, e.g., density, which improves strength; lignin reduction and tree form, which decrease processing costs; disease and pest resistance, which reduce management and protection costs; and adaptability, which allows commercial forests in areas previously unproductive, e.g., drought or cold tolerant and flowering control, which can relieve stigma concerns and costs.

Table 3 lists five promising biotechnological innovations with estimates of their likely benefits. All five innovations involve specialized transgenic transformations to impart traits that involve no additional operating costs, other than seedling costs, which would be expected to be higher since they would incorporate the transgenic technology. Thus, for the five listed innovations, the transgenic tree would provide benefits either through reduced mortality and/or tending costs during the growing cycle, as with reduced weeding costs, or in the form or increased or higher quality final outputs, as with more desired wood characteristics. ${ }^{15}$

The value of these benefits is quantifiable when processing cost reductions are known, e.g., decreased

$\overline{13)}$ The cost savings experienced by the tree independent of any additional costs for the improved seed or seedling.

14) Context Consulting provided information on potential innovations and their likely cost implication based on the best judgment of a panel of experts circa 1997.

${ }^{15}$ ) Many of these traits could, in principle, also be obtained using traditional breeding. digester costs, or the market value of product quality improvement is known, e.g., a premium price can be charged for improved lumber. Thus, if the values of the innovations are captured in a lower cost or a high market price of the product, it would be reflected in higher market prices for the transgenic seed or seedling.

\section{Investments that Shorten the Long Time Frames}

Although the long life of trees imparts forestry with a financial disadvantage, this situation need not be prohibitive. The tremendous expansion of industrial tree planting by the private sector in the last decades of the $20^{\text {th }}$ century, for example, demonstrates that long-term investments in trees can have returns adequate to attractive financial capital.

Additionally, where GE innovations are involved, not all these innovations need await final harvest to experience a financial payoff (table 4). A number of possible innovations have the potential to reduce costs early in the plantation growing cycle. For example, innovations that can reduce establishment costs early in the cycle, such as weeding or pest control costs, will generate benefits early as substitutes for expensive pesticides and through reduced mortality. It is worth noting that the two transgenics trees currently commercialized - the disease resistant papaya and Bt poplar - both generate benefits early in the growing cycle in the form of resistance to disease or pests, the transgenic results in reduced costs early in the rotation for controlling disease and pests. Similarly, herbicide tolerance, an inno- 
vation, an innovation of considerable interest, also would generate financial benefits early in the growing cycle, thereby avoiding the time costs associated with the long forest harvest rotations. The benefits to the tree grower would be captured in reduce weeding costs in the establishment phase, years one through three, of the plantation growing cycle. Flowering control may be viewed as an enabling technology that may not reduce early costs but without which, deregulation cannot be achievable. Alternatively, flowering control may be view as a cost of reducing the probability of lawsuits that could be due to the transgenic pollen "polluting" nearby forests of non transgenic trees.

\section{Costs of Financing Tree Improvements: Some Country Considerations}

Table 5 compares five categories of investment costs required for a transgenic tree in developed and developing countries. For two of the categories the costs appear to be roughly comparable: development and distribution. ${ }^{16)}$ However, for three categories, deregulation, stigma, and time-cost categories, the costs are likely to be substantially lower in developing countries. This finding suggests that the developing countries may have some comparative cost advantages in the commercialization of wood trees.

\section{Development Costs}

A general assumption might be that more economically advanced countries would have an advantage in product development by virtue of their technical expertise and stock of human capital with appropriate training, and this assumption is reflected in table 4. However, while this may be true for some aspects of the development of the basic science, it may not be true for the applied research where lower cost but high technical skills may be available. Typically, the level of technical and research expertise is greater in developed countries. However, labor costs, even for technical people are likely to be much less in developing countries. Furthermore, knowledge and technology are readily transferable across borders (spillovers). Therefore, although the basic technology may be developed in an industrial country, its application to a particular situation and environment may occur more readily in a less developed country, especially countries with high levels of certain technical skills. Finally, it is not clear that intellectual property purchase costs would be different between these two types of countries. However, some developing countries are well know for not respecting intellectual property rights, which has in the past and could give developing countries a cost advantage.

\section{Deregulation by Country}

As noted, stage II deregulation costs are unique to a transgenic product since most newly developed prod-

16) The separation between development and deregulation costs is somewhat arbitrary since some development costs are incurred in order to insure the product can overcome the regulatory hurdle. ucts, even those made through conventional breeding, are not regulated. The costs of deregulation also may vary by country and depend on the nationality of the developer. In the U.S. it has been estimated that tree deregulation is likely to make up at least $50 \%$ of the costs of the initial transgenic development and could be higher (HINCHEE, 2003). More ominously, a recent study suggests that the deregulation process in the U.S. is lengthening and the number of transgenic crops deregulated has decreased sharply in recent years (JAFFE, 2005). Also, PRAY (2005) found that for crop transgenics in India, the deregulation costs were much higher for the foreign firm than for a domestic Indian development firm or a multinational with an Indian partner. However, deregulation costs are likely to be substantially lower if the transgenic in question has already been deregulated elsewhere.

\section{Distribution Costs by Country}

One might argue that more efficient transport, information and general distribution systems in developed countries give them an advantage of low distribution costs over developing countries. Some evidence for this might be found in the quick and efficient distribution of transgenic crops in North America and other developed regions. However, distribution costs for transgenics are treated as roughly comparable between developed and developing countries and this is reflected in table 4.

\section{Country Attitudes - Stigma Costs:}

Despite the stigma associated in some regions with transgenic crops, it is clear that financial returns have been adequate to generate a host of new transgenic agriculture products. While there are numerous similarities between investments in transgenic crops and transgenic trees, there are some important differences. While planting transgenic trees may be viewed negatively in some societies, it is unlikely that there will be a serious stigma attached to the wood itself, and even less to products using transgenic wood. Thus, while harvested and processed food and feed crops may face a stigma in the market, this is unlikely for harvested or processed wood. Thus, the stigma is likely to be associated with acceptance of planting transgenic trees themselves, and less with the products that are subsequently made from them. Nevertheless, the developer may be required to make substantial investments to induce growers to adopt transgenic trees. These investments are likely to be more modest in developing economies where the stigma of transgenics is typically smaller.

\section{Time Costs}

Because many developing countries are found tropical and subtropical regions, a distinct financial advantage exists for nontransgenic tree investments. Trees often grow more quickly in these areas, resulting in a shorter harvest rotation. This has accounted, in part, for the large level of tree plantation investments that has occurred to date in these regions. It would be expected that short rotations would provide time cost financial advantages to transgenic tree innovations, particularly those that were captured only upon harvest. 


\section{Summary of Country Costs}

While developed countries have some advantages in developing GE tree products, particularly at the basic research level, this advantage probably disappears or may be reversed for applied product development. Overall, there appear to be substantial advantages to investments in transgenic tree activities in developing countries. These countries are likely to have cost advantages in deregulation and in lower time-costs due to the usability of tree species with lower rotation ages. While distribution costs appear to be similar in both developed and developing countries, the stigma costs associated with the production of transgenic wood are likely to be small in developing countries compared with many developed countries.

\section{Toward Commercialization and Location: Factors Providing Advantage}

Even given the uncertainties regarding GE trees, it is clear that although some actors want to proceed, others have chosen not to undertaken efforts, or additional efforts in this direction. Whether GE trees for industrial wood purposes have the potential to generate substantial financial and economic returns remains to be determined and has yet to be demonstrated. This section looks at a number of factors that might provide a competitive advantage for transgenic trees and relates these to alternative candidate countries. The assumption is that those interested in capturing the potential financial benefits will move toward locating their activities in countries providing advantages.

Much of the basic research necessary for the development of transgenic trees has already been undertaken and is part of shared knowledge in the scientific community. The techniques for developing a number of applications to trees are well known and, in fact, being applied in laboratories around the world. Most of the remaining challenges are associated with deregulation and public acceptance. The deregulation process is costly, in part because it requires that the deregulation product is judged to be safe from not only a health and safety perspective, but also from an environmental or ecological view. Thus, part of the cost of achieving deregulation could be found in engineering a product that can be judged as safe and environmentally friendly. Extra costs, for example, are likely to be incurred engineering controls such as flowering restrains or sterility. Additionally, the public must also be assured of the safety of the deployment of the transformed tree and the process of achieving public education may be costly.

Given the above considerations, where and how might we expect deregulation to occur and transgenic tree commercialization in the future? Historically, a forest industry was based on the endowment of the forest resource provide by nature. The advent of a viable planted forest together with the growing globalization of the forest industry (BOWYER, 2004) has irreversibly changed that model. A number of factors appear to be relevant to success in plantation and transgenic forestry commercialization. These include prior experience with plantation forests, tree improvement research, the market situation for the final wood product, tree type, ease of deregulation, and country sensitivity to GE products.

\section{Experience and Market Situation}

The organizations with the most direct interest in transgenic forest tree development, deregulation and commercialization are likely to be the developers of the transgenic product and countries/firms that are likely to utilize the innovation and thus be the principal financial beneficiaries of the innovations. These countries/firms are likely to have had substantial prior success with intensively managed plantation forestry. These include Brazil, Chile, New Zealand, South Africa, China, the U.S. South and Australia (table 5). These countries all have had substantial experience with and expertise in intensively managed forest plantations; have large potential markets for innovative trees with substantial commercial potential; have generally low-cost high-yield forests that make them strong competitors; and are in a position to exploit on a large scale this combination of experience, expertise and large domestic markets.

\section{Tree Type}

Another consideration is the types of species which do particularly well in the various countries and the likelihood that tree will be amenable to useful near-term transgenic innovations (table 5). Any widespread transgenic program will require a tree type (species) that can quickly replicated or "bulked up" from a few laboratory developed transgenic trees to millions of low cost seedlings that can be deployed. A problem with conifers has been the difficulty with replication. Techniques for

Table 5. - Comparative Investment Costs: Developed and Developing.

\begin{tabular}{|c|c|c|}
\hline Investment & Developed Countries & Developing Countries \\
\hline $\begin{array}{l}\text { development costs, including } \\
\text { cost required to purchase } \\
\text { requisite intellectual } \\
\text { property(stage I) }\end{array}$ & Comparable & Comparable \\
\hline deregulation costs (stage II) & High & Low \\
\hline $\begin{array}{l}\text { distribution costs and producer } \\
\text { stigma reduction costs (stage } \\
\text { III) }\end{array}$ & Comparable & Comparable \\
\hline $\begin{array}{l}\text { stigma reduction costs for } \\
\text { consumers and } \\
\text { environmentalists(stage IV } \\
\text { cont) }\end{array}$ & High & Low \\
\hline time costs (stage IV) & generally higher & generally lower \\
\hline
\end{tabular}


pine clonal reproduction, such as somatic embryogenesis, have been mastered, but they are still quite costly and are not yet readily for widespread deployment. Thus, countries or regions that depend primarily on conifers are likely to have a delay before the enabling technology, low-cost cloning, is adequately developed.

However, as noted earlier, many deciduous trees, by contrast, are relatively easy to replicate through vegetative propagation. Thus, one might expect the first largescale commercial applications of transgenic trees to be in some type of deciduous tree, which can be easily reproduced. Thus, there are distinct technological and financial advantages in planting a tree that has low propagation cost.

\section{Ease of Deregulation}

Although developing countries do not have a clear advantage in transgenic tree development, at least some developing countries may have a comparative advantage in deregulation. ${ }^{17)}$ As demonstrated in the study by PRAY et al. (2005) a local developer or a multiple national with a domestic partner appears to a have substantial advantage when it comes to achieving fast and low-cost deregulation. The optimum approach may well be to form a joint venture between a biotech development company in the developing world with partners in the countries of interest. The partner can then become the major agent in the deregulation process with both partners sharing the proceeds from the revenues of the deregulated transgenic.

Where developing countries have the technical expertise for the applied stages of the transgenic innovation, the role of the developed country firm might be smaller or non existent. In China, for example, the role of the foreign firm in the development of the transgenic poplar appears negligible. However, some foreign scientists do appear to have played a role and most of the basic research was done elsewhere.

\section{Country sensitivity to GE products}

Finally, there is the question of the country sensitivity (stigma) to GE products and, more generally, commonly shared ecological concerns within a country such as gene escape, which could affect the ease and timing of deregulation. For example, serious concerns have been raised about the implications of gene escape from a transgenic indigenous species, such as loblolly pine in the U.S. to the wild forest population (WILLIAMS, 2004). Such concerns could delay to deregulation of transgenic pine in the U.S., but may raise little concern with an exotic, such as transgenic pine or eucalyptus in Brazil, since there are no native forest trees of the same or related genus (DIFAZIO et al., 2004). A more fundamental way of dealing with this problem may be through neu-

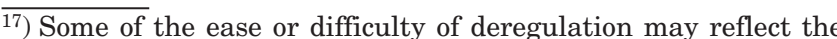
degree of acceptance or hostility to GE within a country. PRAY (2005) finds that deregulation costs appear to be lower in some developing countries, e.g., India, when local firms are involved or the product has been deregulated elsewhere. Chinese experience with poplar tends to support the view that deregulation costs vary by country (Su et al., 2003).
}

tralizing the transgenic pollen (see Mlynarova and Nap 2006 for an example of recent research.

\section{The global market for tree germplasm}

In concept, trade in transgenics can involve two different types of goods: the transgenic tree and its live germplasm, which is available for planting and reproduction, and the commodity wood and products made from that commodity. The commodity produced by the transgenic plant might be corn or industrial wood. Thus, there are two possible industries and two possible markets: that of the tree transgenic produce developer and that of the tree grower. Access to international markets is likely to be different for the two industries.

In general, under the Global Trade Organization (GTO) an innovative commodity is not eligible for international trading restrictions unless deemed to be a health or safety hazard, which has often been the argument against transgenic crops. In the case of wood, however, the commodity would be either raw wood in the form of logs or wood products such as lumber, pulp or paper (SEDJO, 2005). In none of these cases does it appear a serious argument can be made for trade restrictions based on health, safety or concerns of initiating environmental damages in the importing country related to the transgenic nature of the tree, since the wood cells would be dead. ${ }^{18)}$ By contrast, the transgenic germplasm, e.g., the living modified organism (transgenic) plant or its live seed, can be regulated by virtue of the general regulation most countries place on transgenic plants. ${ }^{19)}$

\section{Summary of factors providing an advantage}

The above suggests that GE trees are most likely to become commercial first in countries that a) already have large areas of well functioning plantation forestry and areas for expansion; b) will have access to large markets, either domestically or abroad; and c) have foreign markets unlikely to provide serious barriers of transgenic wood. Also the tree types most likely to be genetically engineered are likely to be nonconifers, due to the high replication costs with conifer. Furthermore, the countries that initiate large-scale commercial transgenic plantation are likely to have a friendly deregulation process and a population that is not overly concerned about transgenic issues and particularly transgenic trees. Finally, the ease of deregulation may depend on the extent of concerns of gene escape to wild forest populations. These concerns may be greater in developed countries where transgenics would be domestic species.

\footnotetext{
18) It is worth noting that despite international agreements under the GTO laying out biosafety criteria, guidelines and conditions under which imports may or may not be banned, the importation of GE products continue to be banned despite meeting the EU biosafety criteria (See ISAAA Crop Biotech Update, 2005).

$\left.{ }^{19}\right)$ However, the ability of a country to prohibit genetically modified crops may be limited. Recently the European Union Court of First Instance ruled that Austria failed to present sciencebased data to justify banning the planting of genetically modified crops (Crop Biotech Update, 2005).
} 
Table 6. - China and Brazil.

\begin{tabular}{|l|l|l|}
\hline \multicolumn{2}{l}{ China } \\
\hline Market size & Large & Large \\
\hline $\begin{array}{l}\text { tree experience: } \\
\text { planted forests }\end{array}$ & Abundant & Abundant \\
\hline Deregulation procedures & modest costs & likely? Modest costs \\
\hline $\begin{array}{l}\text { tree type (ease of } \\
\text { propagation++) }\end{array}$ & $\begin{array}{l}\text { Poplar } \\
++\end{array}$ & $\begin{array}{l}\text { Eucalyptus } \\
++\end{array}$ \\
\hline Public acceptance & Widespread & Widespread \\
\hline Current transgenic trees & yes & No \\
\hline $\begin{array}{l}\text { active tree breeding/GE } \\
\text { research }\end{array}$ & Yes & Yes \\
\hline
\end{tabular}

\section{Countries With Potential Genetic Tree Activity}

Two countries, China and Brazil, appear to have most of the preconditions that would make them early deregulators and commercializers of transgenic trees (table 6). China has most of the listed preconditions for tree deregulation. Additionally, research into GE forest trees was begun in the late 1980s by the Research Institute of Forestry, Chinese Academy of Forestry. A total of 54 GE trees were created (WANG, 2004).

Today, China has deployed limited amounts of transgenic poplars, with a Bt gene to resist insects. China has been establishing very large areas of tree plantations for decades for both protection and commercial industrial wood production purposes (XU et al., 2003). It has markets for industrial wood and has had large rehabilitation and protection efforts under way for some time. China has chosen to commercialize the poplar, a tree whose genome has been well studied. The tree is also very easy to propagate vegetatively. The transgenic poplar released was largely developed in China and apparently was deregulated without inordinate difficulty. The only feature in conflict with the criteria listed above is that gene escape could be transferred fairly readily to the wild poplar population. ${ }^{20)}$

Although its situation is difference in many respects, Brazil also meets almost all the preconditions for transgenic trees. Brazil has large areas of plantation forest and has become a major world supplier of certain types of forest products, e.g., market pulp. Although the tree types in these plantations vary substantially, large areas are in eucalyptus, which has been greatly improved through traditional breeding. It is the eucalyptus that is likely to be the first transgenic forest tree commercialized in Brazil, if Brazil moves to transgenic trees. ${ }^{21)}$

As China, Brazil has been actively involved in research on forest trees with a focus on eucalyptus (ChaIX and MonteuUis, 2004). Domestic concerns about transgenics appear to be minor and, since eucalyptus is an exotic in Brazil, gene escape constitutes little threat to native forests. A possible scenario is that the transgenic eucalyptus will be deregulated and commercially

$\left.{ }^{20}\right)$ However, this could be viewed positively as this might confer pest resistance upon much of the wild tree population that has been under severe insect stress. For a discussion see DIFAZIO et al., 2004.

${ }^{21)}$ Brazil's regulations on transgenics are current in flux (see Cropbiotech 2006, 2006a). planted in Brazil within the next few years. If the productivity gains are anywhere nearly as favorable as anticipated, the ensuing increases in industrial wood production from Brazil over the next couple of decades could be substantial as the productivity on newly planted sites increases even as the area of tree plantations continues to expand.

In general, one would expect the adoption of transgenic trees to be most readily accomplished where the net benefits (benefits - costs) would be greatest and stigma at a low level. In Europe, by contrast with China, Brazil and perhaps other parts of the tropics, the economic gains associated with transgenic trees are likely to be quite modest. The longer growth periods required for maturity bode against the types of high-cost intensive management that are likely to be associated with commercial deployment of transgenic trees. Simply assuming a narrow economic self-interest perspective, it is unlikely that the EU would be very receptive to the importation of transgenic tree germplasm for establishing forests since it has little to gain by taking a positive view of transgenic trees. ${ }^{22)}$ This position, furthermore, is consistent with the overall negative view of EU countries to transgenics plants generally ${ }^{23)}$.

The situation in the U.S. is quite different from either China and Brazil, or Europe. The U.S. has led the world in the development of transgenic technology in agricultural crops (CLIVE, 2004) and now in trees. Most of the agricultural crop transgenics were developed in the U.S. and the largest areas of transgenetic crop plantings have been there. Also, a recent study estimates that roughly one-half of worldwide research on genetic modification generally and nearly one-half of the reported worldwide research the tree genetic modification is taking place in the U.S. (CHAIX and MonTEUUIS, 2004). ${ }^{24)}$ Furthermore, a study by WALTER and KILLERBY (2004) estimates almost two-thirds of the worldwide field trials

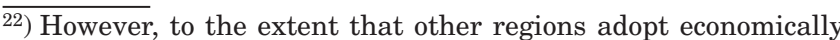
efficient transgenic commercial operations, Europe's competitive position in industrial wood product deteriorates.

23) See Tothova and OEHmke (2005) for a analysis of conditions that my lead to different standards rather than the harmonization of standards

${ }^{24}$ ) CHAIX and MonTEUUIS note that "In Europe forestry research priorities new focus on stronger synergies between biotechnology and conventional selection and breeding programmes for wood improvement.“ (p 48) Tree improvement tends to involve genomic and proteomic approaches to access selection traits rapidly by taking advantage of advances in modern plants. 
of GE trees are undertaken in the U.S. ${ }^{25)}$ However, as noted, crop transgenic deregulation rates and levels in the U.S. has appeared to decline (JAFFE, 2005).

While the U.S. has been a leader in the development, deregulation, deployment and commercialization of transgenic crops, deregulation of a transgenic forest tree may be sometime off. The example of the deregulation of the papaya may be more of an exception than a sign more tree deregulation soon to come.

Being a developed country, the U.S. faces many of the same the obstacles to transgenic regulation listed above that face many developed countries. Much of the country has relatively modest yields and long rotations and therefore the financial advantages of trangenics may be modest at best.. However, some regions enjoy relatively high yields and short rotations, e.g., the South, although these regions are not as favourable as parts of the tropics and subtropics. However, all U.S. regions face the high costs and the long duration of the deregulation process, tree types with relatively long rotation cycles, and opposition, if not a downright stigma associated with transgenic trees. In addition, for the U.S., technical problems exist. Transgenic tree research in the U.S. is oriented toward conifer, particularly pine, and poplar. Both of these tree types are growing in plantations in the U.S. and elsewhere. There are, however, obstacles to the near term deployment of transgenic pine. As noted earlier, pine will need a facilitating low-cost technology in the development of clonal pine. Although progress is being made, further work is needed to develop low-cost applications. In addition, widespread wild pine stands raise questions about the implications of gene escape from transgenic plantation trees (WILLIAMS, 2003). Strauss (in ManN and Plummer, 2002), a well-known tree researcher at Oregon State University, has indicated the view that not until the likelihood that novel genes with new properties will spread to natural forest is minimized will industry be able to introduce transgenic trees into plantations. Although these issues may eventually be adequately addressed, substantial laboratory research and field trials will almost surely be required before deregulation and commercialization is achieved.

While the above considerations suggest relative high costs with the deregulation and deployment of transgenic trees in the U.S., the possibility exists that the tree developments and improvements that take place there could be deregulated and deployed abroad. The opportunities for successful deployment look most promising in regions like South America and southern Africa, and perhaps tropical Asia. Indeed, it may be that the first applications of the deregulated transgenic pine will occur in countries without native pine, e.g., southern hemisphere tropical regions South America or New Zealand. ${ }^{26)}$

25) WALTER and KILLERBY (2004) indicate the U.S. has field tested 103 forest trees, China nine, the countries of Europe a combined total of 23 trials, and the rest of the world 22 .

${ }^{26}$ ) A possible issue here relates to ownership of intellectual property associated with the transgenic and particularly with capturing the rents associated with that property in the context of a foreign country.

\section{Acknowledgements}

The author would like to thank the UN FAO Forestry Department, Rome, Italy where much of this paper was developed while the author was a Visiting Scientist at in summer 2005. He is also thankful to the reviewers of this paper for some excellent comments. However, the views expressed are solely those of the author as are any errors that remain.

\section{References}

Anderson, J. A. and M. K. LuCKeRT (2004): "Financial analysis of hybrid poplar: Is intensive forest management a viable option for priority zoning in boreal regions?" WORKING DRAFT, Department of Rural Economy, University of Alberta, October.

BAILEY, R. (1997): "American Chestnut Foundation." Center for Private Conservation. CEI, Washington, D.C.

BOWYER, J. L. (2004): "Changing realities in forest sector markets," Unasylva, vol. 55, no. 219, pps. 59-64.

CARle, J., P. Vuorinen and A. Del Lungo (2002): "Status and Trends in Global Plantation Development," Forest Products Journal, July/August 2002, vol. 52, No. 7, pages $1-13$.

Carson, M. and Chr. and S. Walter (2004): "The Future of Forest Biotechnology." In: Forest Biotechnology in Latin America, edited by R. Kellison, S. MCCORD \& Kevan, M. A. Gartland. March, pps 13-40.

Chaix, G. and O. Monteuuis (2004): "Biotechnology in the Forestry Sector," chapter 2 in Preliminary review of biotechnology in forestry: including genetic modification, Forest Genetic Resources Working Papers, Forestry Department, FAO, Rome, December.

Clive, J. (2004): Global Status of Commercialized Biotech/ GM Crops: 2004, http// www.agbios.com (Accessed May $25,2005)$.

Convention on Biological Diversity (CBD), Secretariat (2006): Ref: SCBD/STTM/RK/MG/VA/54726.

CropBiotech Update (2005): EU count: Austria can't ban GM planting. October 7, 20058595-return-255-

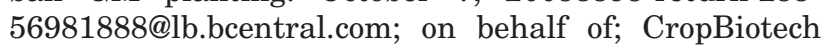
Net [knowledge.center@isaaa.org], http://www.europabio. org.

CropBiotech Update (2006): Brazil's National Biotech Strategy Unveiled. July 7, 2006. http://www.isaaa. org/kc/CBTNews/2006_Issues/July/CBT_July_7.htm\#6

CropBiotech Update (2006a): Brazil: Curtailing Research and Technological Innovations. July 14. http://www. isaaa.org/kc/CBTNews/bcentral/cbt_update.htm\#6

DiFazio, S. P., G. T. Slavov, J. BuRCZYK, S. LeONARDi and S. H. Strauss (2004): Gene flow from tree plantation and implications for transgenic risk assessment. In: Chr. WAlter and M. CARson (eds.). Plantation forest biotechnology for the $21^{\text {st }}$ century. Kerala, India: Research Signpost.

Doty, S. L., Q. T. Shang, A. M. Wilson, A. D. WesterGreen, L. A. Newman, S. E. Strand and M. P. Gordon (2000): Enhanced metabolism of halogenated hydrocarbons in transgenic plants containing mammalian cytochrome P450 2E1. Proc. Natl. Acad. Sciences 97(12): 6287-6291.

EL-LAKANY, M. H. (2004): Äre genetically modified trees a threat to forests? Unasylva 217, vol. 55. (2004/2) pps $45-47$.

FAO (2004): "Agricultural Biotechnology" in The State of Food and Agriculture: 2003-04, Rome. 
FAustmann, M. (1995): "Calculation of the Value which Forest Land and Immature Stands Possess for Forestry," reprinted in the Journal of Forest Economics, 1. pp.7-44.

Fenning, M. and J. Gershenson (2002): Where will the wood come from? Plantation forests and the role of biotechnology. Trends Biotechnol. 20: 291-295.

GOLDMAN, M. L. (2003): Legal perspective on the transgenic papaya licensing program. Paper presented at conference, Modifying Reproduction in Urban Trees, North Carolina Biotechnology Center, February 12-23. mgold@nixonpeabody.com.

Hinchee, M. (2003): Personal communication, April 28, Summerville, NC.

HANCOCK, J. F. and K. E. HoKANson (2004): Invasiveness of transgenic vs.. exotic plant species: How useful is the analogy. In: The Bioengineered Forest, S. STRAuss and H. D. BradshaW, editors, Resources for the Future, Washington, DC.

ISAAA (2005): EU Council fails to lift illegal bans on GM products. Crop Biotech Update, July 1. <CropBiotech\%20Update\%210\%July>.

JAFFE, G. (2005): "Withering on the Vine: Will Agricultual Biocrops Promises Bear Fruit?" Center For Science in the Public Interest, February 2, pps14, http://www.cspinet.org/new/pdf/withering_on_the_vine. pdf (Accessed August 5, 2006).

Mann, C. C. and M. L. Plummer (2002): „Forest Biot Edges out of the Lab." Science, vol. 295, pps: 1626-1629.

MCLeAn, M. A. and P. J. ChAREst (2000): The regulation of transgenic trees in North America. Silvae Genetica 49(6): 233-39.

MlynAROva, L. and J.-P. NAP (2006): “Transgenic Plants that Make non-transgenic Pollen." In: ISB News Report, pps 8-9. http://www.isb.vt.edu/news/2006/ news06.aug.htm\#aug0603 (Accessed August 5, 2006).

Nightingale, P. and P. Martin (2004): "The Myth of the biotech revolution," in TRENDS in Biotechnology, Vol. 22 , No. 11, November.

Pew (2004): "International Agreements: The WTO and the Biosafety Protocol." http://pewagbiotech.org/buzz/ display.php3?StoryID=126. Accessed September 24, 2004.

PraY, C. (2005): "Registration Requirements and Their Costs and Implications: Lessons fro LDCs" Paper delivered to a meeting on the Economics of Regulation of Agricultural Biotechnologies, March 11. Arlington, VA.

Pullman, G. S., J. Cairney and G. Peter (1998): Clonal Forestry and Genetic Engineering: Where We Stand, Future Prospects, and Potential Impacts on Mill Operations. TAPPI Journal 81(2).

RotTManN, W. H., L. M. KLESS and S. ChANG (2005): Acceleration of Flowering in Sweetgum Using LEAFY. http://www.treebiotech2003.norrnod.se/s3_o.htm (accessed 6/01/05).
Rottmann, W. H., R. Meilan, L. A. Sheppard, A. M. BrunNER, J. S. Skinner, C. MA, S. Cheng, L. JouAnin, G. Pilate and S. H. Strauss (2000): "Diverse effects of overexpression of LEAFY and PTLF, a poplar (Populus) homolog of LEAFY/FLORICAULA, in transgenic poplar and Arabidopsis." Plant Journal 22: 235-246.

SEDJO, R. A. (2005): "Global Agreements and U.S. Forestry: Genetically Modified Trees," Journal of Forestry, April/May.

Sohngen, B., R. Mendelsohn and R. Sedjo (1999): "Forest management, Conservation and Global Timber Markets." American Journal of Agricultural Economics 81: 1-13.

Strauss, S. H., A. Brunner, V. B. Busov, C. Ma and R. Meilan (2004): "Ten Lessons from 15 Years of Transgenic Populus Research." In: Forest Biotechnology in Latin America, Proceedings from the Workshop Biotecnologia Forestal, editors R. KeLLison, S. MCCoRD \& M. A. Kevan, Gartland. 2004. PPS 97-106.

Su, X., S. Bing-YU, H. Zhang, Q. Lie-Jian, H. and Z. Xianghua (2003): Advances in tree genetic engineering in China, Paper submitted to the XII World Forestry Congress, Quebec, Canada. September.

Tothova and OenmKe (2005): Biotechnology and Club Behaviour in Agricultural Trade. In: R. E. Evenson and V. SANTANIELlO (eds.). International trade and policies for genetically modified products. Wallington, UK: CABI Publishing, CAB International.

TRAXLER, G. (2005): Presentation on "Agriculture Biotech" to FAO, June 29, 2005. Rome.

WAlter, CHR. and S. KILleRBY (2004): A global study on the state of forest tree genetic modification. In: Preliminary review of biotechnology in forestry: Including genetic modification. Forest Genetic Resources Working Papers. Rome: Forestry Department, FAO, Chapter 3.

WANG, H. (2004): "The state of genetically modified forest trees in China." Chapter 4 in Preliminary review of biotechnology in forestry: including genetic modification, Forest Genetic Resources Working Papers, Forestry Department, FAO, Rome.

Wells, B.: President, ArborGen. Personal conversation. Summerville, S.C. July 20, 2006.

Williams, C. G. (2004): Genetically modified pines at the interface of private and public lands: A case study approach. Paper presented at USDA Forest Service, January 12, Yates Building, Washington, DC.

Xu, Z., M. T. BENNETT, R. TAO and J. Xu (2004): "China's Sloping Land Conversion Program Four Years on: Current Situation and Pending Issues", International Forestry Review 6(3-4): 317-326. 